\title{
In the Midst of Crisis: Knowledge Assets and Operating Efficiency of Italian Listed Companies
}

\author{
Marco Taliento ${ }^{1}$ \\ ${ }^{1}$ Department of Economics, University of Foggia, Foggia, Italy \\ Correspondence: Marco Taliento, Department of Economics, University of Foggia, Via Caggese 1, 71121 Foggia, \\ Italy. Tel: 39-0881-781736. E-mail: marco.taliento@unifg.it
}

Received: April 4, 2017

Accepted: May 25, 2017

Online Published: June 7, 2017

doi:10.5539/ijbm.v12n7p70

URL: https://doi.org/10.5539/ijbm.v12n7p70

\begin{abstract}
Firms' knowledge assets represent vital resources that contribute, in general, to corporate performance and value creation. At an earlier stage, they are expected to help enhance the operational efficiency of firms they belong to. In this light, under a Resource-Based Theory framework, we intend to find whether and to what extent this expectancy is verified also during the recent crisis in Italy. In more detail, we considered 612 firm-year observations relating to the Italian listed companies during three consecutive years - 2010, 2011 and 2012 (when the financial crisis reached its peak in Italy) - analysing overall about 7.000 data/numbers under a Fixed Effects Panel Data Model. The findings are robust: we document a significant positive correlation between Operational Efficiency and Patent assets \& Intellectual Property Rights, Goodwill, Trademarks \& Licenses, while we do not find a correlation with reference to Research \& Development Capital (and Advertising investments), also controlling for employees, leverage and time/sector dummies. In the midst of a very turbulent period, most intellectual assets (the former) appear from the efficiency point of view more valuable and reliable than others (the latter) in hampering the profitability drop. Hence, unlike the tangible and financial assets, such resources are prospected to be strategic levers that make it possible to maintain efficiency or to enable a faster recovery in terms of wasted efficiency. That is, in turbulent times, technology, marketing-related and contractual-legal assets appear significantly associated with operational efficiency and therefore beneficial to corporate results.
\end{abstract}

Keywords: intangibles, efficiency-performance, knowledge intensity, intellectual capital, crisis, panel data

\section{Introductory Notes}

It is well known that knowledge resources are constituted by information or skills within a business that make it more valuable or competitive. Investors and other stakeholders increasingly recognise the growing importance of knowledge assets in the way they value and consider firms (whose knowledge capital is even based on the competencies held by their members).

Coherently, knowledge assets of firms represent vital resources that contribute, in general, to corporate performance and value creation as well (Zanda et al., 2013). Furthermore, they are expected to contribute to enhance the operating efficiency of firms they belong to.

In this light, under a Resource-Based Theory framework, the present paper intends to find whether and to what extent this expectance is verified specifically at the height of the recent crisis in Italy.

In more detail, here we considered 612 firm-year observations relating to the Italian listed companies during three consecutive years - 2010, 2011 and 2012 (when the Italian so-called "spread" reached its peak in terms of highest value, touching more than 500 basis points: this risk premium being the distance between the 10 -year Italian bond and the benchmark, 10-year German bond) -, analyzing overall about 7.000 data/numbers in the context of a Fixed Effects Panel Data Model.

Thus, we searched for a significant (if existent) positive correlation between operational efficiency and knowledge/intellectual capital (R\&D, advertising, patent assets, intellectual property rights, goodwill, trademarks, licenses etc., as accounted and reported in companies' balance sheets and income statements), also controlling for employees, leverage and time/sector (industry) dummies.

Indeed, in the midst of a very difficult and turbulent period like the one taken into account, some knowledge assets might appear from the efficiency point of view more valuable and reliable than others in hampering the 
profitability drop. We measure operational efficiency by means of the Return on Sales financial ratio, because we expect that knowledge resources by implementing innovation should raise sales volume, first of all, and then impact on profit through incremental economic benefits and cost production optimization (ROS is also known as operating profit ratio, providing insight into how much profit is being produced per euro of sales, as it represents how efficiently a company is generating profits from its top-line revenue: it is a powerful and multivalent ratio, as we see later).

That said, the remainder of the paper is organised as follows. The next section (2) provides the theoretical background of the research. Section 3 presents our empirical study and its evidence on the correlation between intellectual capital and operating profitability under the hypothesis that the higher the intangibles per unit of total assets (i.e., in presence of knowledge intensity) the higher the efficiency of companies. Section 4 and 5 express respectively the empirical results and our concluding remarks; while, at the end, there are the bibliographic references.

\section{Theoretical Background}

Firms' knowledge is considered a strategic lever for the competitive advantage and performance, while the business success seems to increasingly depend on the ability to assess, manage and develop the owned knowledge, as well as to attain new knowledge (Davenport \& Prusak, 1998; Schiuma, 2012).

Knowledge capital can be placed at the center of the powerful Resource-Based View (RBV) Theory. The Resource-Based View (Amit \& Schoemaker, 1993; Barney, 1991; Grant, 1991; Hall, 1993), as a theoretical basis for the competitive advantage of firms, lies primarily in the application of a bundle of valuable physical or intangible resources at the firm's disposal (Wernerfelt, 1984; Rumelt, 1984; Penrose, 1959). In order to convert a short-run competitive advantage into a sustained competitive advantage, we need these dominant resources to be: a) heterogeneous in nature and not perfectly mobile (Peteraf, 1993); b) neither perfectly imitable nor substitutable without great effort (Barney, 1991).

The theoretical linkage between business resources and efficiency was introduced by Williamson (1991), showing RBV as an efficiency perspective. Further streams spread from RBV are the Competence Based View (Leonard-Barton, 1995; Prahalad \& Hamel, 1990; Rumelt, 1994) and the Knowledge Based Theory (Grant, 1991; Sveiby, 2001).

Teece (1998) specifically explored the developments in capturing value from knowledge assets and elucidated implications for the management of intellectual capital inside firms [the scholar argued that «the competitive advantage of companies in today's economy stems not from market position, but from difficult to replicate knowledge assets and the manner in which they are deployed» (p. 62)]. Moreover, with the purpose of assessing knowledge assets, Bontis (2001) provided a useful review of a variety of models used to measure intellectual capital highlighting their strengths, weaknesses and operationalizations.

In brief, scholars and entrepreneurs regard the intellectual capital (formed by human capital, structural capital and relational-social capital) as the keystone to achieve and hold a competitive advantage (Lev \& Zambon, 2003; Cricelli \& Grimaldi, 2008), deeming that an effective management of such resources determines positive effects on company performance (Nakamura, 2003).

Knowledge capital would affect corporate performance and they both, in turn, are important pillars of competitiveness; more precisely, we can count several dimensions of competitiveness, among which are (Vilanova et al., 2009): a) Performance, including standard financial measures such as earnings, growth or profitability (Hamel and Prahalad, 1989); b) Quality, not only of products and services, but also a the capacity to satisfy customer expectations (Barney, 1991); c) Productivity, in terms of higher production and lower use of resources (Porter, 1985); d) Innovation, including products and services as well as management processes (Mintzberg, 1993); and e) Image, including corporate branding in terms of building trust and reputation in the relationship with stakeholders (Kay, 1993). Su (2014) documents also that business ethics has positive impacts upon the development of intellectual capital, which, definitely, is today the most powerful source of wealth.

Even in the recent years a number of studies have addressed the issue of how intangible resources help improve business performance and create value for organizations, by focusing on different aspects. In this perspective, Hand \& Lev (2003) pointed out that intangible resources exert a positive impact on market value and business performance, being an indicator of future financial performance. Other scholars also revealed that different stakeholders might attribute a different value to different intellectual components (Chen et al., 2005 and Costa \& Menichini, 2013). In addition, there is evidence that investments in intangible capital (i.e., R\&D, innovation, etc.) have positive effects on a firm value, competitiveness and social responsibility (Huang \& Liu, 2005 and Tan et 
al., 2007).

Generally, the greater efforts a firm devotes to manage the intangible capital, the greater performance and competitive advantage it receives in return (Lu, Wang, Tung, \& Lin, 2010).

Moreover, Houneida \& Arab (2011) document that intangible investments, in the long term, are susceptible to diminish the future earnings volatility and, consequently, the future profits may be measured with reliability and capitalised on the balance sheet as an asset (rather than expensed as a loss) essentially for companies with a strong alignment between the manager's and the shareholder's interest.

Schiuma (2012), stating that management of knowledge is at the core of organization's business growth, underlines that today's managers are interested in managing knowledge not for the sake of knowledge management, but because the planning, design, assessment and revision of the organizational knowledge resources and processes can support the business performance improvements.

Kianto et al. (2013), therefore, deepen the impact of intellectual capital management on company competitiveness and financial performance. Despite the existing research has concentrated on identifying the key intangible resources and measuring their level in various contexts, to their opinion relatively neglected appears the extent to which intangible capital is being managed in companies and how such management impacts on organizational performance (their results, based on data collected from Finnish, Russian, and Chinese companies, demonstrate the importance of a conscious and systematic management of organizational knowledge for the company bottom line). Furthermore, Hirshleifer et al. (2013) find that innovative efficiency, patents or citations scaled by research and development expenditures, are a strong positive predictor of future stocks returns (controlling for firm characteristics and risk).

$\mathrm{Wu}$ and Chen (2014) argue that knowledge resources lay a foundation on the KM-driven performance through the mediator of business process capabilities: more specifically, knowledge assets and process capabilities are two different but relevant drivers in a value creation process.

Denicolai et al. (2014), instead, scrutinize how intangible knowledge assets impact firm international performance (through the analysis of a sample of 290 European listed companies). Drawing upon the knowledge-based view of the firm, they reveal that more knowledge assets have a positive impact on the foreign sales intensity, yet only up to a point.

$\mathrm{Li}$ and Wang (2014) investigated the relationship between intangible assets and financial performance of the listed technology firms in Hong Kong exchange market for a five year period, focusing on research and development cost, employee benefit expense, and sales training (they revealed that R\&D investments and sales training are beneficial to firms' financial performance measured by ROA while employee benefit not).

In addition, recent studies revealed significant changes in investment behavior of firms, as the reduction of willingness to invest in innovation (and then in knowledge) due to the crisis (OECD, 2009; Acemoglu, 2009; Archibugi et al., 2013). This could reduce firms' performances, as obvious.

With specific regard to the 2008 crisis, Teplykh (2017), by applying a structural framework of CDM modelling, evidenced the enhancement of the role of firm resources in the post-recession period in Western Europe, also identifying larger barriers for innovations, increased uncertainty and lower state dependence in R\&D engagement, product creation and economic performance. These findings could indicate a kind of 'cleaning effect', with effects to the business environment and competition.

Antonioli et al. (2011) noted that the recent disruptive economic downturn has forced the (Italian) firms to implement survival strategies even through innovative actions and intervention on product and process areas. Their results suggest the existence of a relationships between past innovative activities and the capacity to react to the challenges brought by the crisis through innovative actions along product, process and organization (human resources) dimensions.

Focusing on Latin America context, instead, Paunov (2012) noted that the longer term impact of the global crisis depends on how business innovation capacities were affected; in brief, the crisis led many firms to stop ongoing innovation projects (the regression results showed that firms with access to public funding were less likely to abandon these investments, whereas younger firms and businesses supplying foreign multinationals or suffering export shocks were more likely to do so).

A further research stream of interest is the so-called value relevance of intangible assets, often providing comparative evidence before and after adopting - in several contexts - the international standards (IFRS), by revisiting the Ohlson (1995) model. In different cases, value relevance appears higher in firms with more reliable 
information on intangible assets (Ji \& $\mathrm{Lu}, 2014)$. Such studies deal with the intangible resources and their financial impact on the firm's value, trying to incorporate the qualitative view focused on intangibles strategy into a quantitative framework to measure the accounting value relevance. In some case studies, the value relevance of voluntary intellectual capital disclosure (rather than mandatory accounting) has been investigated by examining the impact on market value (Ellis \& Seng, 2015).

In literature we learn that the relationship with efficiency (as a determined aspect of business performance), despite its importance, has not been fully developed from the accounting point of view.

Mostly, DEA approach (the economic data envelopment analysis) has been used to measure and explain technical efficiency and its relation to intangibles in specific sectors, especially high-tech (as regards textile and clothing industry see Kapelko et al., 2014).

Pulic (2000), in turn, has studied the efficiency of value added by capital employed and intellectual capital through the Value Added Intellectual Coefficient (VAIC), while Chen et al. (2005) have used VAIC as a measure of intellectual capital to investigate the relationship to market to book value ratio and financial performance as well. As known, VAIC shows the value creation efficiency of the resources employed by the company, dealing with human capital efficiency, structural capital efficiency and (physical and financial) capital employed efficiency (Zéghal \& Maaloul, 2010; Sumedrea, 2013: for a correlation between VAIC and profitability) (Tkachenko et al., 2016).

That said, we believe that during extraordinary time-periods, is more than ever pivotal the governing process that addresses operational efficiency of firms. In this regard, ROA, ROI and ROE are the common ratios employed to evaluate the financial performances, while ROS is empirically less investigated compared to the former ratios: the latter, in our contingent context (intangibles in the midst of a turbulent time), nonetheless is deemed more adequate because knowledge assets are expected to impact the ability to generate both incremental sales (inflows) and differential costs (outflows) / savings of firms, in order to contrast the decline. At last, ROS is one of the most effective indicators of efficiency (Massari et al., 2016) even very useful in corporate valuation in turbulent times, when firms often suffer losses and register negative earnings (Damodaran, 2016; Dudycz et al., 2015). Restructuring firms or startups are special cases suitable for using ROS.

Investors, creditors and other debt holders normally rely on this efficiency ratio because it accurately communicates the percentage of operating income a company actually makes on its revenue and, moreover, can provide insight into potential dividends, reinvestment potential and the company's ability to repay debt. ROS, if studied in conjunction to intangible resources, can reveal how effectively a firm is realizing its core products and services and how its management team runs the business (as known, ROS is a percentage indicator of both efficiency and profitability).

During a crisis ROS can decline because of generally augmented costs and lesser revenues, and could be negative too. On the contrary, the above mentioned ratio is larger when a company's management team is better rationalizing costs and increasing revenue: this process, at last, may be facilitated by an effective use of knowledge resources.

It is worth noting that ROS is even indirectly a driver of pure profitability since it is an implicit component of the (decomposed) ROI ratio (Return on Investment) along with the Capital Turnover (Sales on Invested capital).

Definitely, we may expect that effective intellectual assets and investments in innovation would 'help' the ability of a firm to convert revenues into profits or to lower losses (Hill et al. 2014).

This will support the value creation (or maintenance) through the equation behind the EV/S multiple derived from the financial valuation formulas: $E V / S=R O S(1-t) / w a c c$; where EV/S is the ratio Enterprise Value on Sales; ROS the Return on Sales; $t$ the fiscal rate; wacc the cost of capital invested (Damodaran, 2016).

Moreover, Waddock \& Graves (1997) and Callan \& Thomas (2009) studied ROS ratios in light of the CSR strand (stakeholder view).

In first conclusion, the resource-based view suggests that, in general, intangible capital is able to exert a positive influence on firm performance. In particular, here we consider operational efficiency as a more adequate measure of performance able to support economic value and/or avoid value 'erosion'.

\section{The Empirical Study: Data and Methods}

As premised, we investigated the relationship between knowledge assets of the Italian listed companies and the relating operational efficiency during an extraordinary (crisis) time-period. In more detail, we considered during three consecutive years - 2010, 2011 and 2012 (when the turbulence reached the peak) - a sample of N.o 204 
listed companies (on a total of nearly 250 belonging to the MTA), whose reported data were in that period available for our purpose.

We analysed the intangible assets exposed on the balance sheet (capitalised) and not the intangibles represented by knowledge expenses on the profit and loss account, because the former show more reasonable certainty compared to the potentiality of the latter to be recovered and then (only the former) are actual assets of a company's capital.

From prior literature and common opinion, we can derive that in a crisis-period, despite the sensible uncertainty and high complexity of the context / environment, knowledge capital can be a powerful resource in the hands of management that may help companies to obstacle their own performance decline by acting on operating efficiency processes.

Hence, our Null-Hypothesis is: Knowledge Assets show no significant relation with operating efficiency of the firms examined during the peak years of the crisis.

Since the role of intangibles, we expect to reject that and to identify the specific classes of intangibles with a major efficiency effect or association at least under the hypothesis that knowledge-intensive companies are more efficient.

We selected the following independent variables as main classes of relevant intangibles, identified as reported "non-monetary assets without physical substance":

- Research \& Development Assets (including Advertising capitalizing if applicable);

- Patent Assets and Intellectual Property Rights (including other technology-related assets as software);

- Goodwill from business combinations;

- Other Intangible Assets (as Trademarks / Brands and Licenses, both marketing-related and contractual-legal assets).

The justification of our intellectual variables' selection is in the ascertainment that the above mentioned elements of firms' capital are visibly included and clearly identifiable or accounted for in the annual financial statements of listed companies.

Also, we considered the following controlling variables, to enrich the information about the structure of investments and resources of firms:

- Other Fixed Assets (physical, both non-monetary and monetary - tangible and financial: Property, plant $\&$ equipment, Investments in subsidiaries and associates, etc.);

- Current Assets (Inventories, Trade receivables, Cash funds, etc.);

- $\quad$ Financial Structure (Leverage, as Debt-Equity Ratio = Total Liabilities / Total Equity);

- Human capital entity (natural logarithm of number of Employees).

Our expectations about the control variables during the period in the midst of crisis are a negative 'influence' (rectius, correlation) of bigger dimensions of fixed tangible and financial investments, as well as of employment entity and financial leverage on performances (as indicators of capital rigidity, stringency, financial burden and legal constraints).

The following table (Table 1) reports the descriptive statistics of our sample's variables. The data source is AIDA (Analisi Informatizzata delle Aziende Italiane) - Bureau Van Dijk (some data have been completed manually after consulting the issued financial reports of companies).

Table 1. Descriptive statistics

\begin{tabular}{ccccccc}
\hline Variable & Mean & Min & Max & Std. Dev. & Coeff. of Variat. & Asymmetry \\
\hline ROS & -0.0748 & -47.470 & 29.9700 & 15.0348 & 200.915 & -0.80764 \\
Leverage & 0.9290 & -30.850 & 84.4100 & 5.03054 & 5.41489 & 9.73838 \\
LnEmpl & 5.0247 & 0.0 & 10.8213 & 1.88544 & 0.37524 & -0.02847 \\
R\&D(A)/TA & 0.4358 & 0.0 & 28.4114 & 1.67700 & 3.84836 & 9.4555 \\
PA\&R/TA & 0.4469 & 0.0 & 29.9080 & 2.24526 & 5.02440 & 10.4136 \\
GW/TA & 2.4080 & 0.0 & 50.8902 & 6.69672 & 2.78110 & 3.95268 \\
OIA/TA & 3.9067 & 0.0 & 66.7586 & 10.1634 & 2.60149 & 3.60372 \\
OFA/TA & 51.8241 & 3.0002 & 98.9700 & 26.9583 & 0.52019 & -0.003461 \\
CA/TA & 40.9786 & 1.3001 & 97.000 & 24.9490 & 0.60883 & 0.36666 \\
\hline
\end{tabular}

Note. Our elaboration of collected data. 
Original data, from $R \& D(A)$ to $C A$, are expressed in $K$ Eur, while knowledge capital elements reported have been finally scaled on total assets (TA) to enable our analysis and allow comparisons.

We note that, on average, companies demonstrate a barely negative percentage of operational efficiency (from a minimum of $-47 \%$ to a maximum of $30 \%$ ) yet a substantially balanced financial leverage ratio (nearly 1 , although high is its variability / volatility). On average, $R \& D(A)$ and Patents/Rights represent about $12 \%$ of the knowledge assets, while goodwill amounts to $1 / 3$ and other intangible assets, e.g. trademarks and licenses (and works in progress), exceed 50\%. Patents \& Rights evidence high variability / volatility, almost double than the remaining resources.

As regards time variations (from 2010 to 2012), the variables R\&D(A)/TA and PA\&R/TA denote a U shaped curve, while GW/TA increases and OIA/TA decreases.

The following table reports the interesting pairwise correlations.

Table 2. Pearson's correlations

\begin{tabular}{|c|c|c|c|c|c|c|c|c|c|}
\hline ROS & Lev & LnEmpl & $R \& D(A) / T A$ & $P A \& R / T A$ & GW/TA & OIA/TA & OFA/TA & $C A / T A$ & \\
\hline \multirow[t]{16}{*}{1} & -0.1039 & 0.2356 & 0.0277 & 0.0135 & 0.1004 & 0.1334 & -0.3096 & 0.2177 & $R O S$ \\
\hline & $(*)$ & $(* *)$ & & & $(* *)$ & $(* *)$ & $(* *)$ & $(* *)$ & \\
\hline & 1 & -0.0219 & 0.0148 & 0.0153 & -0.0134 & -0.0092 & 0.0078 & -0.0035 & Leverage \\
\hline & & 1 & 0.1271 & -0.0047 & 0.3093 & 0.0946 & -0.2242 & 0.1074 & LnEmpl \\
\hline & & & $(* *)$ & & $(* *)$ & $(*)$ & $(* *)$ & $(* *)$ & \\
\hline & & & 1 & 0.0368 & 0.0809 & -0.0367 & -0.1641 & 0.1001 & $R \& D(A) / T A$ \\
\hline & & & & & $(*)$ & & $(* *)$ & $(*)$ & \\
\hline & & & & 1 & 0.0667 & 0.0181 & -0.1827 & 0.0797 & $P A \& R / T A$ \\
\hline & & & & & & & $(* *)$ & $(*)$ & \\
\hline & & & & & 1 & 0.0270 & -0.2129 & -0.0608 & GW/TA \\
\hline & & & & & & & $(* *)$ & & \\
\hline & & & & & & 1 & -0.2807 & -0.1105 & $O I A / T A$ \\
\hline & & & & & & & $(* *)$ & $(* *)$ & \\
\hline & & & & & & & 1 & -0.8816 & OFA/TA \\
\hline & & & & & & & & $(* *)$ & \\
\hline & & & & & & & & 1 & CA/TA \\
\hline
\end{tabular}

Note. Our elaboration of data: $(* *)$ Correlation significant at 0.01 level (2-tailed); $(*)$ at 0.05 level (2-tailed).

From the above, we may learn that several variables are correlated to each other through statistically significant coefficients, but never so high to raise multicollinearity phenomena.

We can note that ROS (operating efficiency ratio) is positively correlated to GW and OIA, in addition to the human capital represented by the number of employees, as regards knowledge assets; a positive correlation is also registered with current capital, while a negative pair-correlation is revealed with both tangible and financial fixed assets and leverage ratio.

Shedding light on knowledge resources, we underline that Research \& Development Capital (including Advertising if applicable) is positively related to goodwill (and current capital) but negatively (as Patents Assets, Rights and Other intangible assets do) to tangible and financial fixed assets; GW is negatively related to OFA (that in turn is negatively related to CA) too. Interesting is noting that the number of employees is positively related to all the components of knowledge assets (and negatively to OFA).

As regards the multiple regression analysis (in order to learn more about the relationship between the several independent or predictor variables and the dependent variable), we opted for the Fixed-Effects Panel Data Model, after executing the preliminary Breusch-Pagan (1980) Lagrange-multiplier and Hausman (1978) tests to control for Pooled OLS and/or GLS (Random Effects). This technique is advanced and commonly used in this kind of research.

Since CA/TA and FA/TA are complement to 1, we eliminated CA/TA from the inferential model for possible mathematical collinearity and obvious redundancy (for example, an excessive increase of fixed capital related to total assets implies an inefficient use of working capital which reduces the enterprise's ability to carry accounts receivable and maintain inventory and usually means a low cash reserve). No clue for other collinearity concern 
derived from correlation coefficients of above. However, we performed the VIF analysis (on variance inflation factors), obtaining adequate results (Minimum VIF: 1.0; Collinearity problem: VIF $>10$, where VIF(j) $=1 /(1$ $R(j)^{2}$ ), and $R(j)$ is the multiple correlation coefficient between the $j$ variable and the other independent variables); VIFs are reported as follows:

- Leverage: 1.002

- LnEmpl: 1.152

- $\quad \mathrm{R} \& \mathrm{D}(\mathrm{A}) / \mathrm{TA}: 1.051$

- PA\&R/TA: 1.045

- GW/TA: 1.145

- OIA/TA: 1.103

- OFA/TA: 1.258

An estimate of the covariance matrix that is robust with respect to heteroskedasticity and autocorrelation (and hence also robust standard errors) has been necessary. The robust estimator here is the one suggested by Arellano (2003), which is HAC (that is, heteroskedasticity and autocorrelation consistent). It considers the matrix of regressors (X, with the group means subtracted, in the case of fixed effects), the vector of residuals for unit (i) and the number (n) of cross-sectional units (this variance estimator is also known as the "clustered - over entities" estimator).

The Ramsey Reset Test for misspecification in linear regression (on preliminary OLS) revealed that the specification was adequate, although we found the FE model superior.

We introduced two time-dummies to control the dynamics of efficiency and a sector/industry dummy.

The linear regression can be expressed by the equation:

$$
\begin{gathered}
\text { OER }=\text { const. }+b_{1} R \& D(A) / T A+b_{2} P A \& R / T A+b_{3} G W / T A+b_{4} O I A / T A+b_{5} \text { OFA/TA }+b_{6} \text { LnEmpl }+ \\
b_{7} \text { Leverage }+b_{8} d t_{-} 2+b_{9} d t_{-} 3+b_{10} d_{-} s+\varepsilon_{i}
\end{gathered}
$$

whose results are summarised by the following table (Table 3 ) along with the main regression statistics - where OER is the Operational Efficiency Ratio (return on sales, with operating profit adjusted before intangibles' depreciation if applicable):

Table 3. Panel Data Model - Fixed Effects, Dep. variable OER

\begin{tabular}{lcccccc}
\hline Predictors & Coefficient & Std Coeff. & Std. Error & t-statistic & $p$-value \\
\hline const & 0.488601 & - & 19.3203 & 0.0253 & 0.97984 \\
R\&D(A)/TA & -0.008634 & -0.000969 & 0.241967 & -0.0357 & 0.97156 \\
PA\&R/TA & 0.532237 & +0.079483 & 0.28082 & 1.8953 & 0.05915 & $(*)$ \\
GW/TA & 0.511237 & +0.227712 & 0.288144 & 1.7742 & 0.006398 & $(* * *)$ \\
OIA/TA & 0.388156 & +0.262390 & 0.172823 & 2.2460 & 0.02554 & $(* *)$ \\
OFA/TA & -0.078204 & -0.140225 & 0.0787142 & -0.9935 & 0.32137 & \\
LnEmpl & -0.474289 & -0.059478 & 3.82624 & -0.1240 & 0.90144 & \\
Leverage & -0.272885 & -0.091304 & 0.20789 & -1.3126 & 0.19046 & $(* * *)$ \\
dt_2 & 2.647350 & - & 0.855408 & 3.0948 & 0.00218 & $(* *)$ \\
dt_3 & 3.082061 & - & 1.07947 & 2.8552 & 0.00464 & $(* *)$ \\
d_s & $y e s$ & - & & & & \\
\hline
\end{tabular}

Regression Statistics:

\begin{tabular}{lrlr}
\hline Depend. Var. Mean & -0.257972 & Depend. Var. Std Dev. & 15.05012 \\
\hline Sum Squared Errors & 14999.70 & Standard Error & 7.552025 \\
R-squared & 0.847062 & Adjusted R-squared & 0.748205 \\
F(14, 199) & 8,568558 & P-value(F) & $1.22 \mathrm{e}-52$ \\
Log Likelihood & -1384.594 & Akaike Criterion & 3111.188 \\
Schwarz Criterion & 3807.679 & Hannan-Quinn & 3386.108 \\
rho & -0.260745 & Durbin-Watson & 1.713637 \\
\hline
\end{tabular}

Note. Our elaboration of data: $(* * *)$ level of significance $1 \% ;(* *)$ level of significance $5 \%$; $(*)$ level of significance $10 \%$. HAC: heteroskedasticity robust standard errors and autocorrelation consistent. 


\section{Results}

Intangible resources appear positively correlated with operational efficiency of firms, as measured by ROS, in the context that we have scrutinised (Italian Listed Companies in the midst of the financial crisis).

We found that the intangible assets 'predictors', except $R \& D$, have positive regression coefficients which are statistically significant.

A said, we adopted a Panel Data Model - Fixed Effects. The presence of heteroskedasticity detected by the White's test (along with the Durbin-Watson statistics of autocorrelation of residuals slightly below 2), suggested us to perform heteroskedasticity robust standard errors.

The findings are robust: we find a significant positive correlation between operational efficiency and Patent assets \& (Intellectual Property) Rights, Goodwill, Trademarks \& Licenses, while we cannot confirm the correlation with reference to Research \& Development Capital (and Advertising investments). We controlled for different years and industry sectors through dummy variables (dt_2 referring to 2011; dt_3 referring to 2010; d_s to industry).

As major results relevant for our purpose, we indicate the positive coefficients associated to PA\&R/TA $(+0.53$; p-value 0.059$)$, to GW/TA ( +0.51 ; p-value 0.006$)$, and to OIA/TA ( +0.39 ; p-value 0.025$)$.

The Confidence Intervals at $95 \%$ parameter of each variable reported denoting statistical significance are as follows:

- PA\&R/TA: $(-0.0207055,1.08518)$

- GW/TA: $(-0.0561249,1.07860)$

- OIA/TA: $(0.0478633,0.728448)$

- dt_2: $(0.963026,4.33166)$

- dt_3: $(0.956552,5.20756)$

It is worth noting that we may also identify a positive support of $\mathrm{R} \& \mathrm{D}(\mathrm{A})$ considering their amount in t-1 (coefficient 0.294171; $\mathrm{p}$-value $<0.1 \%$ ).

In addition, willing to jointly investigate the potential 'impact' of intangibles on efficiency, we register the sum of coefficients related to the knowledge assets of firms considered as a whole [R\&D(A)/TA + PA\&R/TA + $\mathrm{GW} / \mathrm{TA}+$ OIA/TA] $=+1,423$ (std error $0.783983 ; \mathrm{t}(263)=1,81508 ; \mathrm{p}$-value $=0.07065)$. That implies the rejection of the null hypothesis at a level of significance between $5 \%-10 \%$.

In substance, knowledge assets appear to exert a positive effect on (or however denote a positive correlation with) efficiency/performance. More correctly, we may draw that they are systematically associated.

Physical - tangible and financial assets (non-monetary and monetary: Property, plant $\&$ equipment, Investments in subsidiaries and associates, Available-for-sale investments, etc.) instead do not show the same relationship (their coefficient is slightly negative and not significant too).

As regards control variables of our model, both the number of employees and the financial leverage show a negative relation, although not statistically significant (Archibugi et al., 2013).

Finally, about GoF, the adjusted R-squared of the selected regression model (75\%), as well as the overall significance of the statistical outcome expressed in terms of F-test (p-value $<0.1 \%$ ), appears consistent and good, showing values that confirm the validity of the empirical analysis carried out, in terms of both the predictive ability of the model used and the overall adequacy of the theorised construct. In this regard, even the use of further firm-specific control variables (as a sector dummy separating financial from industrial firms) did not affect the main findings, while the passing of time showed to be associated with a decreasing level of operating efficiency of reported firms (figuring a climax in the crisis or a persisting turbulence).

To be precise, it is not superfluous noting that while we can surely document association between our selected variables, we cannot infer causality (strict causality requires a panel data covering many more years and fortunately for the observed economy we do not owe such massive data, concerning a very long-term crisis). However, in line with theory, we are confident that the systematic association could be interpreted as a (co-)casuality relationship since it is reasonable to expect that factors of production (inputs), among whom intangibles, someway affect processes efficiency and profitability of firms (outputs); as said, knowledge resources by implementing innovation can raise sales volume and then may impact profit through incremental economic benefits and cost production optimization. On the contrary, the possible effect of profitability on new 
investments (aiming to higher performance) should be proved from cash flow analysis in a much wider period of turbulent time. Finally, even though the predicted variable and the predictors were simply correlated each other, this would imply they are devoted to a common end (value creation).

\section{Concluding Remarks}

Nowadays the OECD economies are more strongly dependent on the production, distribution and use of knowledge than ever before. The knowledge-based capital involves intangible assets of firms (e.g. R\&D, Patents, trademarks, human capital and more in general the organisational space and design) that are essential for fully realising productivity gains and efficiencies from innovation and new technologies (OECD, 2011; 2013). Innovation, in turn, involves the production of new knowledge from complementary assets; as such, intangible assets become a strategic factor in a firm's performance and value creation (Corrado et al. 2012).

During crisis-time, intellectual or intangible assets may be still an effective instrument to maintain the economic value of firms enhancing productivity and ensuring acceptable levels of efficiency.

Hence we analysed the linkage between intangible resources and efficiency, adopting the RBV as an efficiency perspective. Therefore, our work focused on the measurement of intangibles of the Italian Listed Companies, with the purpose of assessing their potential predictor role in firm's operating efficiency during the financial crisis (in the midst of turbulence).

Previous literature deepened more the impact of intangibles on financial or market performance rather than on efficiency itself. Under a hybrid approach, we selected the Return on Sales, because it is a multivalent and powerful ratio. Indeed, ROS is recognised as one of the most effective indicators of efficiency (Massari et al., 2016) even very useful in corporate valuation in turbulent times, when firms often suffer losses and register negative earnings (Damodaran, 2016; Dudycz et al., 2015).

We tried to measure the degree of the contribution of intangible assets in the prediction of the future performance / efficiency since it is expected, with a reasonable certainty, that they are capable of future economic advantages or recoveries.

We provide evidence that firms' knowledge assets represent vital resources that contribute, in general, to corporate performance and value creation, and, before that, to enhance the operational efficiency of firms they belong to.

Our empirical study is based on 612 firm-year observations relating to the Italian listed companies during 2010/2012 (when the Italian "spread" reached the peak), analyzing overall about seven thousand data/numbers in the context of a Fixed Effects Panel Data Model. The findings are robust: we find a significant positive correlation between operational efficiency and Patent assets \& Intellectual Property Rights, Goodwill, and Trademarks \& Licenses, while we cannot confirm the correlation with reference to Research \& Development Capital (and Advertising investments) (although theoretically meaning advances of knowledge and productivity; Pakes \& Griliches, 1984; Baum et al., 2017). As a consequence, in this turbulent context, most intellectual assets (the former group, especially trademarks \& licenses, and goodwill, whose coefficients are more confidently positive) appear from the efficiency point of view, more reliable than the remaining ones (the latter class) in hampering the profitability drop (ROA and ROE are negative).

Hence, we learn that such resources are more stable, as well as strategic, levers that make it possible to maintain efficiency or enable a faster recovery in terms of efficiency (often negative too).

In our case $R \& D(A)$ spending by itself, likely due to major uncertainty, inherent risk and time consumption, does not guarantee efficiency nor profitability tout court at least immediately (indeed, 1-year lagged values revealed positive correlation). In this regard, it is important to underline that a large part of $R \& D(A)$ is not capitalised, but expensed in the income statement, so the controlled activities (those shown in the balance sheet as assets) are partial elements of a bigger picture. Additionally, Houneida \& Arab (2011) found that the intangible costs recorded in the expenses of the accounting exercise (i.e., the R\&D expenditures) may not have a predictive power of the future economic performance (moreover, in Italy, Research activities and Advertising can no longer be capitalised from 2016 due to the Legislative Decree n. 139/2015, so that they can express no more fixed capital, but operating costs; only Development investments are allowed to capitalization and be part of knowledge assets for the future). In this regard, previous researches have demonstrated that there is no short run relationship between such investments (that are a determinant of the success of new products; Troy et. al. 2008) and corporate performance, because it takes time for them to reveal their contribution (Li \& Wang 2014; who after arguing that in literature the influence of these investments on performance remains controversial - suggest lagged R\&D expenditure as an instrumental variable to examine the long term effect on performance). 
In brief, our results partly confirm Ambrammal \& Sharma (2016)'s empirical investigation (based on manufacturing firms), finding that firms' patenting (and intellectual property rights) result in productivity and financial performance improvement of firms, whereas R\&D does not. The same we may say as for goodwill from business combinations and trademarks / licenses: the value of the going concern acquired, the synergistic element from integration and the commercial power of a brand or of an agreement are all pivotal factors that may facilitate even in difficult situations, by virtue of their powerful features, the business processes and results.

In short, corporate investments in such intangibles show to be correlated to better efficiency-performance, even acting like both a kind of parachute and the flywheel of the future recovery / development of firms (business policy and strategy indication).

A limitation of the work is in that it does not enable to automatically extend the findings to other performance indicators as ROA, ROI or ROE (from a supplementary analysis these ratios earned no significant correlation, except for a positive role of goodwill on ROA and ROI levels, and a negative correlation between ROE and leverage) and to other economies characterised by different institutional, accounting information and environmental factors. We did not detect correlation either to cash flow to assets. Another limitation is in the awareness that the financial reporting of intangibles scrutinised is not always guarantee of quality of intangibles.

In conclusion, in line with the resource-based view's suggestions, the intangible capital of the analysed sample differently from the other fixed assets, both tangible and financial - mostly showed a positive association with firm performance (see also Zanda et al., 2013). More specifically, since in the midst of a financial crisis the classical performance indicators of firms may be not reliable (due to negative earnings and/or poor cash flows tendency and higher volatility), we can consider the operational efficiency (proxied by the return on sales ratio) as a measure of performance more complete, credible and informative. The findings support our hypothesis and document that during turbulent times firms characterised by knowledge intensity are operationally more efficient than the others, especially due to the precious technology, marketing-related and contractual-legal assets at their disposal.

\section{References}

Acemoglu, D. (2009). The Crisis of 2008: Lessons for and from Economics. Critical Review, 21(2-3), 185-194. http://dx.doi.org/10.1080/08913810902933788

Ambrammal, S. K., \& Sharma, R. (2016). Impact of patenting on firms' performance: an empirical investigation based on manufacturing firms in India. Economics of Innovation and New Technology, 25(1), 14-32. http://dx.doi.org/10.1080/10438599.2015.1043767

Amit, R., \& Schoemaker, P. J. H. (1993). Strategic assets and organisational rent. Strategic Management Journal, 14. http://dx.doi.org/10.1002/smj.4250140105

Antonioli, D., Bianchi, A., Mazzanti, M., Montresor, S., \& Pini, P. (2011). Economic crisis, innovation strategies and firm performance. Evidence from Italian firm-level data. SIE annual meeting.

Archibugi, D., Filippetti, A., \& Frenz, M. (2013). Economic crisis and innovation: Is destruction prevailing over accumulation? Research Policy, 42(2), 303-314. http://dx.doi.org/10.1016/j.respol.2012.07.002

Arellano, M. (2003). Panel Data Econometrics. Oxford University Press. http://dx.doi.org/10.1093/0199245282.001.0001

Barney, J. (1991). Firm Resources and Sustained Competitive Advantage. Journal of Management, 17(1), 99-120. http://dx.doi.org/10.1177/014920639101700108

Baum, C.F., Lööf, H., Nabavi, P., \& Stephan, A. (2017). A new approach to estimation of the R\&D-innovationproductivity relationship. Economics of Innovation and New Technology, 26(1-2), 121-133. http://dx.doi.org/10.1080/10438599.2016.1202515

Bontis, N. (2001). Assessing knowledge assets: A review of the models used to measure intellectual capital. International Journal of Management Reviews, 3(1), 41-60. http://dx.doi.org/10.1111/1468-2370.00053

Callan, S. J., \& Thomas, J. M. (2009). Corporate financial performance and corporate social performance: An update and reinvestigation. Corporate Social Responsibility and Environmental Management, 16(2), 61-78. http://dx.doi.org/10.1002/csr.182

Chen, M. C., Cheng, S. J., \& Hwang, Y. (2005). An empirical investigation of the relationship between intellectual capital and firms' market value and financial performance. Journal of intellectual capital, 6(2), 159-176. http://dx.doi.org/10.1108/14691930510592771 
Corrado, C., Haskel, J., Jona-Lasinio, C., \& Iommi, M. (2012). Intangible capital and growth in advanced economies: Measurement methods and comparative results. IZA discussion paper No. 6733, Institute for the Study of Labor (IZA), Bonn. http://ftp.iza.org/dp6733.pdf

Costa, R., \& Menichini, T. (2013). A multidimensional approach for CSR assessment: The importance of the stakeholder perception. Expert Systems with Applications, 40(1), 150-161. http://dx.doi.org/10.1016/j.eswa.2012.07.028

Cricelli, L., \& Grimaldi, M. (2008). A dynamic view of knowledge and information: A stock and flow based methodology. International Journal of Management and Decision Making, 9(6), 686-698. http://dx.doi.org/10.1504/IJMDM.2008.021221

Damodaran, A. (2016). Damodaran on valuation: Security analysis for investment and corporate finance (Vol. 324). John Wiley \& Sons. http://dx.doi.org/10.1002/9781119201786

Davenport, T. H., \& Prusak, L. (1998). Working knowledge: How organizations manage what they know. Boston, Harvard Business School Press. http://dx.doi.org/10.1145/347634.348775

Denicolai, S., Zucchella, A., \& Strange, R. (2014). Knowledge assets and firm international performance. International business review, 23(1), 55-62. http://dx.doi.org/10.1016/j.ibusrev.2013.08.004

Dudycz, T., Osbert-Pociecha, G., \& Brycz, B. (Eds.) (2015). The essence and measurement of organizational efficiency. Springer. http://dx.doi.org/10.1007/978-3-319-21139-8

Ellis, H., \& Seng, D. (2015). The Value Relevance of Voluntary Intellectual Capital Disclosure: New Zealand Evidence. Corporate Ownership \& Control, 1071. http://dx.doi.org/10.22495/cocv13ilc9p9

Grant, R. M. (1991). The Resource-Based View of Competitive Advantage: Implication for Strategy Formulation. California Management Journal, 33, Spring. http://dx.doi.org/10.2307/41166664

Hall, R. (1993). A framework linking intangibles resources and capabilities to sustainable competitive advantage. Strategic Management Journal, 14, 607-618. https://10.1002/smj.4250140804

Hamel, G., \& Prahalad, C. K. (1989). Strategic Intent. Harvard Business Review, 3, 63-76.

Hand, J. R., \& Lev, B. (Eds.) (2003). Intangible Assets: Values, Measures, and Risks: Values, Measures, and Risks. OUP Oxford.

Hill, C. W., Jones, G. R., \& Schilling, M. A. (2014). Strategic management: theory: an integrated approach. Cengage Learning.

Hirshleifer, D., Hsu, P. H., \& Li, D. (2013). Innovative efficiency and stock returns. Journal of Financial Economics, 107(3), 632-654. http://dx.doi.org/10.1016/j.jfineco.2012.09.011

Houneida, B. B., \& Arab, M. B. (2011). The efficiency of accounting normalization in the matter of intangibles: Asset versus Expense. International Journal of Accounting and Financial Reporting, 1(1), 72. http://dx.doi.org/10.5296/ijafr.v1i1.762

Jen Huang, C., \& Ju Liu, C. (2005). Exploration for the relationship between innovation, IT and performance. Journal of Intellectual Capital, 6(2), 237-252. http://dx.doi.org/10.1108/14691930510592825

Ji, X. D., \& Lu, W. (2014). The value relevance and reliability of intangible assets: Evidence from Australia before and after adopting IFRS. Asian Review of Accounting, 22(3), 182-216. http://dx.doi.org/10.1108/ARA-10-2013-0064

Kapelko, M., \& Oude Lansink, A. (2014). Examining the relation between intangible assets and technical efficiency in the international textile and clothing industry. The Journal of the Textile Institute, 105(5), 491-501. http://dx.doi.org/10.1080/00405000.2013.826417

Kay, J. (1993). Foundations of Corporate Success. Oxford, OU Press. http://dx.doi.org/10.1093/019828988x.001.0001

Kianto, A., Andreeva, T., \& Pavlov, Y. (2013). The impact of intellectual capital management on company competitiveness and financial performance. Knowledge Management Research \& Practice, 11(2), 112-122. http://dx.doi.org/10.1057/kmrp.2013.9

Leonard-Barton, D. (1995). Wellspring of knowledge. Harvard Business School Press, Boston, MA.

Lev, B., \& Zambon, S. (2003). Intangibles and intellectual capital: an introduction to a special issue. European Accounting Review, 12(4), 597-603. http://dx.doi.org/10.1080/0963818032000162849 
Li, H., \& Wang, W. (2014). Impact of Intangible Assets on Profitability of Hong Kong Listed Information Technology Companies. Business and Economic Research, 4(2), 98. http://dx.doi.org/10.5296/ber.v4i2.6009

Lu, W. M., Wang, W. K., Tung, W. T., \& Lin, F. (2010). Capability and efficiency of intellectual capital: The case of fabless companies in Taiwan. Expert Systems with Applications, 37(1), 546-555. http://dx.doi.org/10.1016/j.eswa.2009.05.031

Massari, M., Gianfrate, G., \& Zanetti, L. (2016). Corporate Valuation: Measuring the Value of Companies in Turbulent Times. John Wiley \& Sons. http://dx.doi.org/10.1002/9781119261674.ch1

Mintzberg, H. (1993). The Rise and Fall of Strategic Planning. New York, Free Press.

Nakamura, L. (2003). A trillion dollars a year in intangible investment and the new economy. In Hand, J. R., \& Lev, B. (Eds.). Intangible Assets: Values, Measures, and Risks. OUP Oxford, 19-47.

OECD (2009). Policy Responses to the Economic Crisis: Investing in Innovation for Long-Term Growth. OECD Publishing, Paris.

OECD (2011). Sources of growth. Science, Technology and Industry Scoreboard 2011. OECD Publishing. http://dx.doi.org/10.1787/sti_scoreboard-2011-5-en

OECD (2013). Supporting Investment in Knowledge Capital, Growth and Innovation. OECD Publishing, Paris. http://dx.doi.org/10.1787/9789264193307-5-en

Ohlson, J. A. (1995). Earnings, Books Values, and Dividends in Equity Valuation. Contemporary Accounting Research, Spring: 661-687. http://dx.doi.org/10.1111/j.1911-3846.1995.tb00461.x

Pakes, A., \& Griliches, Z. (1984). Patents and R\&D at firm level: A first look. In Griliches, Z. (Ed.). R\&D, Patents, and Productivity. Chicago: NBER and University of Chicago Press. http://dx.doi.org/10.3386/w0561

Paunov, C. (2012). The global crisis and firms' investments in innovation. Research Policy, 41(1), 24-35. http://dx.doi.org/10.1016/j.respol.2011.07.007

Penrose, E. T. (1959). The Theory of the Growth of the Firm. New York: Wiley. http://dx.doi.org/10.1093/0198289774.001.0001

Peteraf, M. A. (1993). The Cornerstones of Competitive Advantage: A Resource-Based View. Strategic Management Journal, 14 (3): 179-191. http://dx.doi.org/10.1002/smj.4250140303

Pew Tan, H., Plowman, D., \& Hancock, P. (2007). Intellectual capital and financial returns of companies. Journal of Intellectual capital, 8(1), 76-95. http://dx.doi.org/10.1108/14691930710715079

Porter, M. E. (2008). Competitive advantage: Creating and sustaining superior performance. http://simonandschuster.com

Pulic, A. (1998). Measuring the performance of intellectual potential in knowledge economy. 2nd McMaster Word Congress on Measuring and Managing Intellectual Capital by the Austrian Team for Intellectual Potential.

Rumelt, D. P. (1984). Towards a Strategic Theory of the Firm; Alternative theories of the firm, 2002, (2), 286-300. Elgar Reference Collection, International Library of Critical Writings in Economics, 154.

Schiuma, G. (2012). Managing knowledge for business performance improvement. Journal of Knowledge Management, 16(4), 515-522. http://dx.doi.org/10.1108/13673271211246103

$\mathrm{Su}, \mathrm{H}$. Y. (2014). Business Ethics and the Development of Intellectual Capital. Journal of Business Ethics, Vol. 119, Issue 1, pp. 87-98. http://dx.doi.org/10.1007/s10551-013-1623-4

Sumedrea, S. (2013). Intellectual capital and firm performance: a dynamic relationship in crisis time. Procedia Economics and Finance, 6, 137-144. http://dx.doi.org/10.1016/S2212-5671(13)00125-1

Sveiby, K. E. (2001). A knowledge based theory of the firm to guide strategy formulation. Journal of Intellectual Capital, 2(4), 344-358. http://dx.doi.org/10.1108/14691930110409651

Teece, D. J. (1998). Capturing value from knowledge assets: The new economy, markets for know-how, and intangible assets. California Management Review, 40(3), 55-79. http://dx.doi.org/10.2307/41165943

Teplykh, G. V. (2017). Innovations and productivity: the shift during the 2008 crisis. Industry and Innovation, 1-31. http://dx.doi.org/10.1080/13662716.2017.1286461

Tkachenko, E., Rogova, E., \& Bodrunov, S. (2016). Intellectual Capital Assessment and Financial Indicators for 
Value-Based Management: The Joint Application. International Conference on Intellectual Capital and Knowledge Management and Organisational Learning, Academic Conferences International Limited.

Troy, L. C., Hirunyawipada, T., \& Paswan, A. K. (2008). Cross-functional integration and new product success: An empirical investigation of the findings. Journal of Marketing, 72(6), 132-146. http://dx.doi.org/10.1509/jmkg.72.6.132

Vilanova, M., Lozano, J. M., \& Arenas, D. (2009). Exploring the Nature of the Relationship Between CSR and Competitiveness. Journal of Business Ethics, 87(1), 57-69. http://dx.doi.org/10.1007/s10551-008-9812-2

Waddock, S. A., \& Graves, S. B. (1997). The corporate social performance - financial performance Link. $\begin{array}{llll}\text { Strategic Management } & \text { Journal, } & \text { 303-319. }\end{array}$ http://dx.doi.org/10.1002/(SICI)1097-0266(199704)18:4<303::AID-SMJ869>3.0.CO;2-G

Wernerfelt, B. (1984). The Resource-Based View of the Firm. Strategic Management Journal, 5(2), 171-180. http://dx.doi.org/10.1002/smj.4250050207

Williamson, O. E. (1991). Strategizing, economizing, and economic organization. Strategic Management Journal, 12(S2), 75-94. http://dx.doi.org/10.1002/smj.4250121007

Wu, I. L., \& Chen, J. L. (2014). Knowledge management driven firm performance: The roles of business process capabilities and organizational learning. Journal of Knowledge Management, 18(6), 1141-1164. http://dx.doi.org/10.1108/JKM-05-2014-0192

Zanda, G., Lacchini, M., \& Onesti, T. (2013). La valutazione delle aziende (Vol. 9). G. Giappichelli, Turin.

Zéghal, D., \& Maaloul, A. (2010). Analysing value added as an indicator of intellectual capital and its consequences on company performance. Journal of Intellectual Capital, 11(1), 39-60. http://dx.doi.org/10.1108/14691931011013325

\section{Copyrights}

Copyright for this article is retained by the author(s), with first publication rights granted to the journal.

This is an open-access article distributed under the terms and conditions of the Creative Commons Attribution license (http://creativecommons.org/licenses/by/4.0/). 